\title{
Widows Of Vrindavan - Feminisation Of Old Age In India
}

\author{
Rekha Pande \\ Department of History \\ University of Hyderabad, Telangana, Iidia
}

\begin{abstract}
The present paper looks at some of the issues of the old women with a special focus on widows of Vrindavan. In 2009, there were 88 million elderly people in India. By 2050, this figure is expected to soar over 320 million. By 2050, women over 60 years would exceed the number of elderly men by 18.4 million, which would result in a unique characteristic of 'feminisation' of the elderly population in India. The gendered nature of ageing is such that universally, women tend to live longer than men. In India, social mores inhibit women from re-marrying, resulting in an increased likelihood of women ending up alone. The life of a widow is riddled with stringent moral codes, with integral rights relinquished and liberties circumvented. In many conservative Indian Hindu families, widows are shunned because they're seen as bringing bad luck. Most of these widows find refuge in Vrindavan. Here they lead a very miserable life mostly begging and singing hymns in praise of God. However, this year saw a change in the condition of these women due to the initiative of Sulabh International, which takes care of two shelter homes where more than 800 widows have been registered and for the first time after they became widows many women played Holi (a festival of colours)excising their agency in a small way. The paper concludes by stating that there is very little information available on these widows. There is a need for better data collection and research on the social and economic status of widows, and on inheritance practices. Last but not least let us treat the widows as human beings and bring them into the main stream of the Women's Movement.
\end{abstract}

Key Words: Vrindavan, Widows, Old Age, Problems, Sociology

$$
\begin{aligned}
& \text { تلخيص }
\end{aligned}
$$

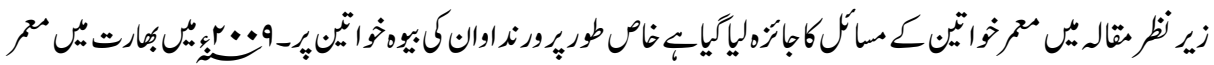

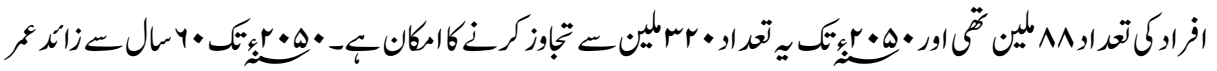

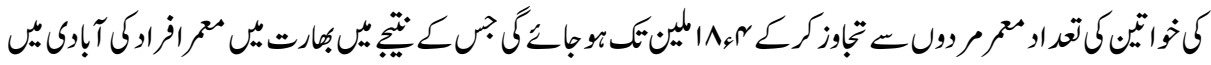

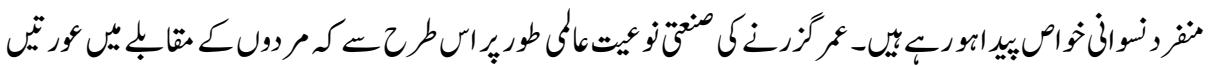

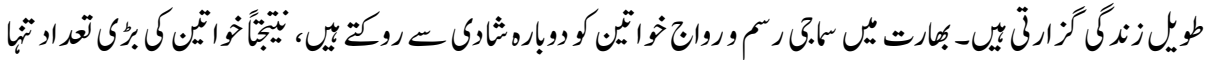

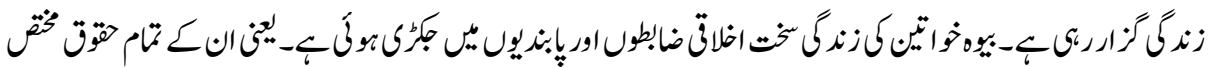

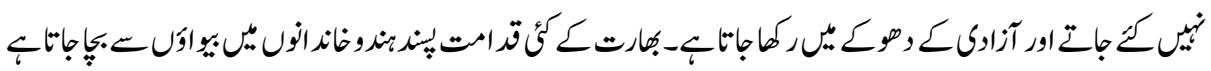

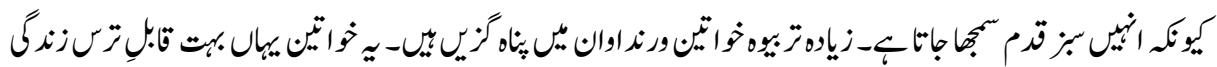




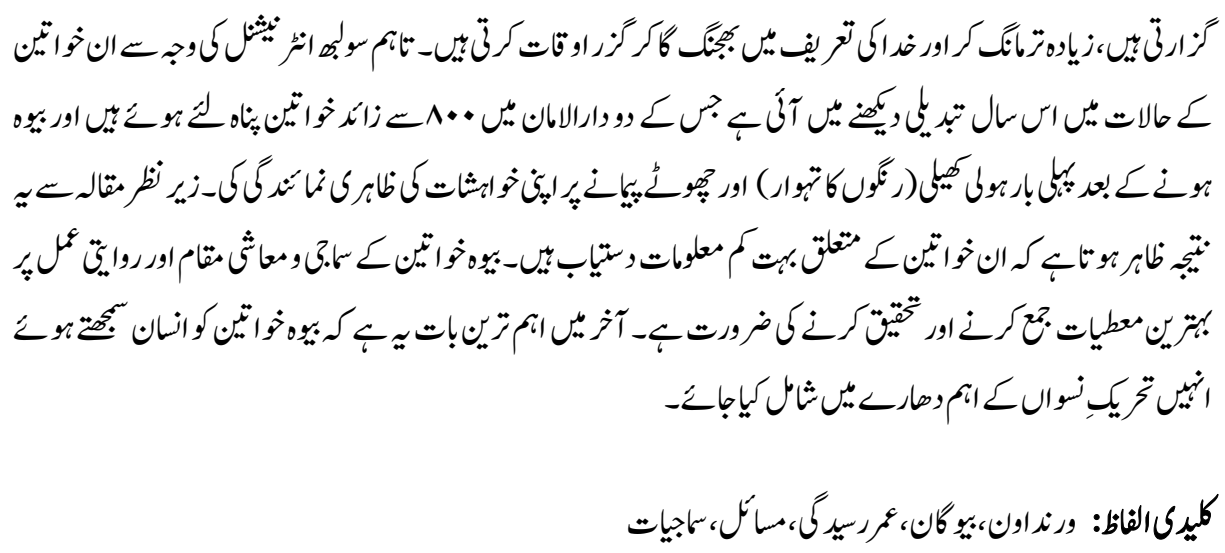

Ageing is not Lost Youth but a New Stage of Opportunity and Strength. Betty Friedan (1921-2006).

Women face prejudices nor only for being women but also for being old. The predicament of elderly women is aggravated by a life time of gender-based discrimination. It is a well-known fact that two of the most populous nations in the world, India and China contribute nearly $38 \%$ of the global elderly population. With the advancement in medical sciences and good health care facilities has brought about a change in the number of people surviving up to a very old age.

In 2009, there were 88 million elderly people in India. By 2050, this figure is expected to soar over 320 million. Investment in the elderly population is no longer a question of choice. By 2050, women over 60 years would exceed the number of elderly men by 18.4 million, which would result in a unique characteristic of 'feminisation' of the elderly population in India. Improved life expectancy has contributed to an increase in the number of persons 60+ from only 12 million persons 60+ in India in 1901, the number crossed 20 million in 1951 and 57million in 1991. Population projections for 1996-2016 made by the Technical Group on Population Projections (1996) indicate that the 100 million mark is expected to be reached in 2013. Projections beyond 2016 made by the United Nations has indicated that India will have 198 million persons 60+ in 2030 and 326 million in 2050. The percentage of persons $60+$ in the total population has seen a steady rise from 5.1 per cent in 1901 to 6.8 per cent in 1991 . It is expected to reach 8.9 per cent in 2016. Projections beyond 2016 made by United Nations (1996 Revision) has indicated that 21 per cent of the Indian population will be $60+$ by 2050. ( Report, National Policy on Older persons).

The concept of the 'feminisation of poverty' is used extensively in the development debate and it has meant three distinct things: that women compared to men have a higher incidence of poverty; that women's poverty is more severe than men's; and that the 
incidence of poverty among women is increasing compared to that of men.( Wennerholm , 2002,9). The same concept can be applied to old age women for these women are more than men, the number of old women is increasing and the poverty of these women is much more than that of men. For aging women for concept of feminisation is not only a consequence of lack of income, but is also the result of the deprivation of capabilities and gender biases present in both societies and governments (Chant, 2006). This includes the poverty of choices and opportunities, such as the ability to lead a long, healthy, and creative life, and enjoy basic rights like freedom, respect, and dignity and this applies to older women. In recognising that longevity was becoming one of the major challenges of the 20th century, the United Nations convened World Assembly on Ageing in Vienna in 1982. The purpose of the World Assembly would be to provide a forum "to launch an international action programme aimed at guaranteeing economic and social security to older persons, as well as opportunities to contribute to national development". In its resolution 35/129 of 11 December 1980, the General Assembly further indicated its desire that the World Assembly "should result in societies responding more fully to the socio-economic implications of the aging of populations and to the specific needs of older persons"( Vienna International plan of action on aging, 11983 ). It was with these mandates in view that the present International Plan of Action on Aging was conceived. It formulated a package of recommendations which gives high priority to research related to developmental and humanitarian aspects of ageing (United Nations, 1987). The plan of action specifically recommended that "International exchange and research cooperation as well as data collection should be promoted in all the fields having a bearing on ageing, in order to provide a rational basis for future social policies and action. Special emphasis should be placed on comparative and cross-cultural studies in ageing". The phenomenon of population ageing is becoming a major concern for the policy makers all over the world, for both developed and developing countries, during last two decades. But the problems arising out of it will have varied implications for underdeveloped, developing and developed countries.

\section{International Policy}

That same year the UN General Assembly endorsed the International Plan of Action on Ageing. In 1990, the Assembly designated October 1 as the International Day for the Elderly, later renamed the International Day of the Older Persons. The UN General Assembly decided in 1992 to observe the International Year of Older Persons in 1999 to raise awareness of the fast changing demographic picture of older persons, to stimulate debate, promote action strategies, and encourage research and information exchange. The theme of the year is 'towards a society for all ages'.

The Madrid International Plan of Action on Ageing and the Political Declaration adopted at the Second World Assembly on Ageing in April 2002 mark a turning point in how the 
world addresses the key challenge of "building a society for all ages". It has been a decade since the adoption of the Madrid International Plan of Action on Ageing (MIPAA). Its bold agenda focused on three priority areas: older persons and development; advancing health and well-being into old age; and ensuring enabling and supportive environments. ( Madrid International Action Plan on Ageing). The Division for Social Policy and Development (DSPD) is part of the Department of Economic and Social Affairs (DESA) of the United Nations Secretariat. The Division seeks to strengthen international cooperation for social development, DSPD Ageing is the focal point within the United Nations system on matters related to ageing. As the focal point, its primary action is to facilitate and promote the Madrid International Plan of Action on Ageing, including designing guidelines for policy development and implementation; advocating means to mainstream ageing issues into development agendas; engaging in dialogue with civil society and the private sector; and information exchange.( Aging, Social Policy and development division).

In order to address this unprecedented demographic shift it is necessary to understanding the challenges of an ageing population. A joint study by the United Nations Population Fund and Help age International called 'Global Report on Ageing' seeks to fill the knowledge gap. It was released nationwide on October 1, 2012, on the International Day for Older People.

\section{Ageing Differently}

Old age is a natural part of the life-cycle. It is a process of regular changes that occur in mature and genetically representative organism living under representative environmental conditions as they advance in chronological age. These changes can be anatomical, physiological, psychological and even social and economic. Biologists are of the opinion that aging begins when growth and development stops. Psychological aging consists of a general decline in the mental abilities that accompany old age. Generally, physical aging precedes mental aging though this is not always the case. The sociological aspect of individual aging is concerned with changes in the circumstances or situations of individual as a member of the family, community and society (Soodan, 1995, 1) The problem of ageing women in a sense brings together many gender issues. Geriatric care is compounded with many things: the economic condition of the aged, among whom women are the majority; the insufficiency of the elderly women's own resources to supplement the state's old age pension; the conditions that are attached to social security entitlements for women and the bases on which those entitlements rest; the employment history of women which cumulatively leads to their relative deprivation vis-a-vis men as well as the young; family changes that have reduced family care systems and the heavy demographic burden of the high proportion of the elderly coupled with the inactive adults among working age groups (Krishnaraj, 1999, 75) 


\section{Government of India Policy}

Government of India adopted 'National Policy on Older Persons' in January, 1999. The policy defines 'senior citizen' or 'elderly' as a person who is of age 60 years or above (Report, 2011, Situation analysis of elderly in India).

As a signatory to MIPAA, India has the responsibility to formulate and implement public policy on population ageing. Issues of poverty, migration, urbanisation, ruralisation and feminisation compound the complexity of this emerging phenomenon. Public policy has to respond to this bourgeoning need and mainstream action into developmental planning. Gender and social concerns of elderly, particularly elderly women, must be integrated at the policy level. The elderly, especially women, should be represented in decision making. Benefits of social schemes must percolate to the grassroots. Increasing social/widow pension and its universalization is critical for expanding the extent and reach of benefits. Besides this the government has created social security schemes such as National Old Age Pension and Widow Pension Scheme.

Latest in the line of policy documents, the first ever national policy on older persons of India, refers to the legal rights of parents who have no means to seek the support of their children having sufficient means. It was formulated by the ministry of social justice and empowerment and submitted for cabinet approval in January 1999. Some analysts have tried to see how far it is sensitive to the mandate for gender parity and removal of gender discrimination.

By and large, there is not much emphasis to highlight the gender implications of such a policy despite evidence that women in this category suffer greater vulnerability. In the sections on healthcare, nutrition, shelter and education, there is no specific reference to women's situation. What is interesting is there are pointed references to the changing nature of the family and the roles of younger women who are potential care-givers, and therefore, older persons tend to be seen as burdensome. The document exudes a tone of alarm while making these observations. However, at the implementation level it will be the panchayatraj institutions who will take the initiative in implementation. (Gopal, 2006, 4480). In 1999, the government of India announced Annapurna, a national social assistance scheme for elderly destitute. Under this scheme the destitute old person would be provided $10 \mathrm{~kg}$ of rice or wheat per month free through the public distribution system (PDS). It is implemented by the ministry of rural development with the assistance of the ministry of food and civil supplies.

Some of the issues facing the aged women in India include marginalisation/isolation or alienation in old age. In India the joint family system has now been replaced by nuclear families and the old age home are still shunned for there is a strong bias against them. 
Older women, who are still living with their sons/daughters and grand-children are also suffering from emotional alienation. With increased life span of older women, their financial needs are emerging as major concerns in old age. However, today many older women have property/money but they cannot use the money or take financial decisions on their own as social traditions don't allow them to use their ancestral property / money for their own welfare. In old age women turn towards religion. Most women turn to religious activities, pilgrimage, etc. after losing their life-partner or any other family members in today's fast paced modern life, younger generations hardly find time to share with their elders. It has been realised that ever-widening communication gap between the generations is also responsible for miserable condition of older women.

According to the medical practitioners, old age depression is a very rampant problem today, and the sorrier thing is that the number of cases each year is only increasing. It is a myth that old age depression happens only in countries with poor old age plans; today it is also happening in the most advanced countries of the world with the best long term plans. The situation has become so grave that in most cases depression and elderly women have almost become synonymous. Most elderly women in the world suffer from some kind of depression or the other. With depression among elderly women, it is necessary to give them as much time as possible to make them feel wanted. A careful analysis of old age depression shows that this condition occurs generally when elderly women feel that there is no one to look after them. If the depression continues, then it could take a toll on the heart or it could complicate into major mental problems. Depressed women might need someone to converse with. That is why care homes that care to them take the efforts to make depressed elderly women feel involved in all the activities that they undertake. (Bevinemar, 2012

One of the major issues of the aged is the acute health problems. The aging of India's population will lead to increases in the prevalence of chronic conditions such as diabetes and hypertension. By one measure, nearly one-half (45 percent) of India's disease burden is projected to be borne by older adults in 2030, when the population age groups with high levels of chronic conditions will represent a much greater share of the total population. The majority of households use poor-quality cooking fuel, and the resulting smoke produced contributes to indoor air pollution and tends to have a particularly negative impact on older persons who spend more time indoors. Today, there is a lack of younger people who can take care of the elderly women as was done in joint families. This is due to several factors, including declining fertility leaving fewer children available to care for older parents, rural-to-urban migration for employment that separates families, and changing social expectations regarding interfamily obligations.

Numerous examples are found in the rural areas where women who are married into rich peasant households might find them economically vulnerable or are driven to work on the 
farms of their well-off brothers or brothers-in-law, or even beg for livelihood upon death of or desertion by their husbands. Of these the conditions of widows and older women is the most vulnerable (Chen, 1998).

Despite India's recent rapid economic growth, the majority of older Indians remain poor. Less than 11 per cent of them have a pension of any sort, according to national surveys. Saving is difficult or impossible for a majority of Indians because earnings are low, some economic activity in the informal sector does not involve currency exchange, and a large share of the aging population lives in a rural area where banking is unavailable. With little old-age income support and few savings, labour force participation remains high among those ages 60 and older, particularly among rural Indians. Evidence suggests that not only does a large share of the elderly earn income, they also support their adult children who often live in homes and work on farms owned by their parents.

\section{Widows in India}

The gendered nature of ageing is such that universally, women tend to live longer than men. In the advanced age of 80 years and above, widowhood dominates the status of women with 71 per cent of women and only 29 per cent of men having lost their spouse. In India, social mores inhibit women from re-marrying, resulting in an increased likelihood of women ending up alone. The life of a widow is riddled with stringent moral codes, with integral rights relinquished and liberties circumvented. Social bias often results in unjust allocation of resources, neglect, abuse, exploitation, gender-based violence, lack of access to basic services and prevention of ownership of assets. Ageing women are more likely to get excluded from social security schemes due to lower literacy and awareness levels.

Death often does not have just a biological aspect to it but it has a social aspect to it. A death does not just mean the end of a life of one individual but a lot of sufferings for the one's; left behind. For in the Indian situation death of an individual is a loss to the society no doubt but it creates a number of socio- economic problems for the children in the family and more so for the wife who is left behind and branded as a "Widow". The practice of widowhood was structurally integrated into the ideology and material relations of the caste system in India. By abandoning coloured clothes, spicy food and leading a life of celibacy and existing in a spiritual plane the widow embraced social death when her husband died. Hindu women did not inherit property under the dominant legal system of Mitakshara and Dayabhaga and denied of any property or productive resources the widow was totally depended on the mercy of the male members in the family, This very term, widow, is used negatively and is very backward looking. A widow's life is full of misery. She suffers from social, economic and cultural constraints. Her day to day life becomes a struggle to survive in a patriarchal world. In many Indian 
societies, if a husband passes away, the wife bears the blame for her husband's death which is considered a manifestation of the wife's past sins. Considered a bad omen, widows are often abandoned by their families, left destitute, and forced to beg for daily survival. In many societies women marry at an early age and to men much elder than them. Hence they survive much longer than men. The "in auspiciousness" of a Hindu widow is well known. She is stigmatised as a woman who has failed to safeguard her husband's life. Under ancient law, her husband is God, and when he dies she is expected to manifest inconsolable grief for the rest of her life. The extreme consequence of this belief is the practice of sati - where a wife immolates herself on her husband's funeral pyre. Although made a criminal offence in the last century and in spite of further legislation in recent times, sati still occasionally occurs in the backward villages of rural North India.

Local interpretations of the custom of the caste determine whether or not a widow will be granted some permanent or temporary share of the joint family's land or property.

In rural India, land ownership tends to engender the bitterest family disputes - never more intense than when a husband dies. A full account of land inheritance in India would have to distinguish between I) traditional law 2) modern law, and 3) actual practice.

The inheritance rights of the majority of Indian rural widows are governed by actual practice. Practice can differ from village to village, even in the same region and among the same caste.

If a widow has adult sons, she may enjoy - but not always - some measure of security, and on her husband's death she may remain in the house, and share the household income. But if she is childless or has only daughters, she usually faces problems. Indian women, especially in the north, are not so likely to work in agriculture as those are in Africa. The gender division of labour is greater in a "plough" culture, rather than a "hoe" one. So even if a widow is left with land, she is unable to cultivate it without male management.

Although the Hindu Succession Act 1969made women eligible to inherit equally with men and some individual states have legislated equality provisions into inheritance law widows are mostly deprived of their legal rights. Patrilocal residence and patrilineal inheritance (the wife goes to live in her husband's village; only males can inherit) is a fundamental source of the poverty and marginalisation of Indian widows. An Indian wife becomes the property of her in-laws family, and when her husband dies they can decide what to give her and how to treat her. Having broken all intimate ties with her birth family, when her husband dies a widow has no freedom to "return" to the parental home, or to her brothers. She remains in her husband's village whether or not her owned land or property. If there is land, under most caste codes the widow should be allotted some for 
her needs, but she is not given ownership rights; she cannot mortgage, sell or gift it away. She only has the "use" and very limited rights. Inspite of various reforms widow remarriages is impossible and rarely done. If she marries away "going for nata", has no children, is judged to behave badly, she may be sent away. The reality is that limited as they are, the accepted property rights of widows are often violated in practice.

In a Chen study in 1994, 30\% of the widows reported serious conflicts over inheritance, land, property, residence. Conflicts often ended in violence. Conflicts over land and property are often so bad that brothers-in-law force the widow to leave the village. Conflicts are usually of two types: the brothers-in-law insist on sharecropping or managing the widow's land themselves, or they simply deprive her of her share (often rationalizing their claim by arguing that they spent money on her husband's funeral or on her children's maintenance; they might even bring up the dowry question and say that money was owed). Even if she owns land, she may have no access to wells, ploughs and bullocks. In their attempts to gain control of land and property, the brothers-in-law may (often abetted by their wives) harass, persecute, beat and torture and even arrange the murder of the widow. To exercise full ownership rights by inheritance a widow would have to be literate, courageous, and mobile. She would need to be able to assert her claim dealing with (male) officials at Land Registries and with lawyers. For a rural widow this is impossible. Her status as a widow prohibits her from leaving the house; she cannot afford to travel to the nearest town; she is ignorant of the rules and she cannot fill up a form or sign her name. She is completely unequipped to deal with the bureaucracy, confront male strangers, and in seeking outside assistance she lays herself open to more gossip, verbal abuse and violence.

Some castes prohibit remarriage, others allow it provided that it is within the family. If a widow marries away (going for nata), she loses all rights to her children, land and any possessions. The higher the caste the more likely it is that widow remarriage is forbidden. There are exceptions: a child widow or a young childless widow may usually remarry. If the widow is very young, her parents may arrange another marriage for her. If they are poor and cannot afford another dowry, the second marriage is often full of problems - the husband may be an elderly widower, a divorcee, or sick and handicapped. There is an emerging trend towards prohibiting and discouraging remarriage even in the lower and middle castes as a means of achieving higher social status but most widows interviewed do not wish to remarry. They fear ill treatment in a new family, especially abuse of their children. (Drez, Chen, 1995). In some cases leviratic marriage is practised: the widow is taken in by a brother.

The overall probability that a widow will remarry is quite low, perhaps of the order of 15 to $20 \%$ in India as a whole (Chen 1994). It is not therefore a viable refuge for the majority of widows who have children at the time of losing their husband. 
There is much variation from caste to caste as far as mourning rites are concerned. Generally, widows in lower castes are freer than those in the higher ones. Brahmin widows are probably under the strictest limitations on their life-style. Wearing a white sari without a bodice. Foregoing all decoration and cosmetics: no bangles, nose ring, flowers, kumkum (red brow spot symbolizing marriage); jewelry; foregoing to relish, pickle, spices and eating only bland food Never singing or dancing Remaining in seclusion and avoiding social gatherings such as weddings and puja (temple worship) Never looking at any man outside the immediate family .Forced remarriage to a brotherin-law or a levirate. Living the remainder of her life (this could be the greater part) as an ascetic in the harsh conditions of Ashrams or a temples.

Many of these mourning rites, if complied with in extreme, are responsible for the high morbidity and mortality of Indian widows. They eat badly, they become malnourished and ill and at the same time they are often badly treated in the homes of unwelcoming relatives.

Gender-related domestic violence is well documented in India: sati; dowry-death through bride burning; female feticide; son preference; wife beating are all phenomena which have increased in recent years.

In many conservative Indian Hindu families, widows are shunned because they're seen as bringing bad luck. Superstitious relatives even blame them for their husband's death. The widow can become a liability with no social standing, an unwanted mouth to feed. Often they're cast out of the family home. "According to the Dharmashastra, the sacred Hindu legal text, covering moral, ethical and social laws, widows are expected to devote the remainder of their lives to the memory of their husbands. For many women in this culture, the loss of a husband can be an upheaval beyond belief. It can be a one-way ticket to isolation, poverty and despair. Considered inauspicious, many soon find they have lost their income and are ostracised in their home villages. Some are sent away by their husbands' families who want to prevent them inheriting money or property. Most of these widows find refuge in Vrindavan.

Vrindavan, on the banks of river Yamuna, in Uttar Pradesh, a few hours' drive south-east of Delhi, traditionally the "City of Temples", has now been apparently rechristened as the "City of Widows" due to refuge sought by thousands of Hindu widows disowned by their families Krishna, according to great epic the Mahabharata, was born in the nearby forest and it was around here that the young flute-playing trickster flirted with the cow herders - the gopis - and enjoyed that love affair known to every Hindu with the beautiful, divine Radha. The ancient name of the city, "Brindaban," had been named after its ancient groves of "Brinda," Ocimumtenuiflorum, or Tulsi, with ban meaning a grove or a forest. Two small groves still exist, Nidhivanand SevaKunj. This lies in the Braj region 
which has been made famous in the Bhakti ( religious Literature). It is about $15 \mathrm{~km}$ away from Mathura city, the birthplace of Lord Krishna. Vrindavan is a place where custom seems frozen in time despite its proximity to such symbols of resurgent India. It is believed that Vrindavan had been completely forgotten till it was rediscovered by Chaitanya Mahaprabhu in the 16th century. In 1515, he visited Vrindavan with the purpose of locating the lost holy places associated with Lord Krishna. Chaitanya wandered through the forests of Vrindavan and it is believed that through his spiritual powers, he was able to locate all the important places of Krishna's times in and around Vrindavan. In the last 250 years, the extensive forests of Vrindavan have been threatened, first by local Rajas and in recent decades by real estate developers. The forest cover has been whittled away to only a few spots, and the local wildlife, including peacocks, cows, monkeys and a variety of bird species, has been exposed to various threats. Nobody can quite explain why this particular town attracts widows from all around India - particularly, it seems, from Bengal.

In Vrindavan, India, widows of all ages are waiting for the moment they, too, will follow their husbands to the fields of death. The widows in Vrindavan today can be found on the streets, in ashrams and other centers in Vrindavan. Vrindavan has over 4,000 temples today and many ashrams. The approximate number of widows living in the holy city today numbers over 20,000. It is impossible in this short briefing to describe the life of an Indian widow in detail since there are great variations depending on state, caste, economic and social level, education and whether the family is rural or urban. Broadly speaking, the widows in the north suffer greater discrimination and marginalisation than widows in the south. But the higher the caste, the greater may be the restrictions on a widow's life style. Thus, a widow from a relatively well off family may be subject to greater cruelty and abuse by her in-laws than a lower caste widow who is freer to work outside in the public space, and to remarry.

Old and young, these widows sing hymns in temples in order to earn a livelihood. They have been living in such wretched conditions despite the efforts of the Government and aid agencies to improve their lives. Conditions in some of the ashrams of Vrindavan go from terrible, human trafficking of younger widows occurs. Their daily work is to go to bhajan ashram and sing for about 3-4 hours per day. These bhajan ashrams are run by rich religious people. They give Rs. 5 and a little bit of rice and a little bit of lentils (Daal-Chawal) to each widow chanting for three hours. Not just any widow can enter in any bhajan ashram and start chanting and then get some money. They have to get registered with the ashram first and then their timing is decided and only then they can work. A part from this is sad to see that most of the widows living in Vrindavan are involved in begging for surviving. Some of the young beautiful widows face the terrible fate of sexual trafficking and sexual exploitation as the ashrams try to produce more money. 
It's sad to see them being subjected to such an awful existence in a country when women are worshipped as goddesses. Regardless of their age, they are forced to wear white attire and are expected to lead a dreadful life. So much so that they are not even allowed to attend any ceremony as her presence is considered a bad omen. According to a United Nations Development Fund for Women study, many widows don't even come to Vrindavan voluntarily. They are often escorted by their relatives, who leave them with no intention of taking them back ever.

A seven-member panel, appointed by the Supreme Court to conduct a survey of the socio-economic condition of the Vrindavan widows in Uttar Pradesh, today told the court that they are "highly vulnerable" groups, living in "pathetic" conditions. In an eight-page report placed before a bench of Justice D K Jain, the panel said the widows are being exploited by the various NGOs there."Only those who go to such places unannounced and without any official clout can see and realise the pathetic conditions in which the destitute women known as Vrindavan widows live there and the way in which they are exploited," the report said. It said the welfare measures meant for the widows are not reaching them and it is being taken away by others.( Report, NCI, 2009-10). "At present, the NGOs who run the homes for homeless behave like jail warden and the inmates are under the rule of their thumbs, the report said adding "it is said that some of them snatch away money from the destitute women when a lump sum amount is received by such women." "There are stories that some of the NGOs use the name of the destitute women for collecting the welfare funds on multiple occasions by showing such woman as resident of different Sadans," the report added. Taking note of the report, the bench said it is for the state government to act for improving the situation and listed the matter for August 3 for passing directions. The apex court had on May 9 appointed the panel headed by the Mathura District Legal Services Authority chairman to conduct an enumeration of the widows living in the city. The committee also comprised the representatives of the National Commission for woman, those from the Uttar Pradesh government, district collector, district medical officer and Mathura's senior superintendent of police. ( The Hindu, July, 30, 2012).

However, this year saw a change in the condition of these women and the fact that these women did have an agency however limited. The change in the lifestyle of widows in Vrindavan is primarily due to the initiative of Sulabh International, which takes care of two shelter homes where more than 800 widows have been registered. Here their basic needs are taken care of, in addition to Rs2,000 being given every month to each woman. These women are now learning to read and write English, besides getting vocational training in making agarbattis, garlands, etc. These small steps have instilled a sense of security among these women. It began by distributing a stipend of Rs 1,000 per month (which was last month raised to Rs 2,000), providing medical facilities, teaching them to read and write and giving providing means to earn a living. The task, however, is 
enormous. Sulabh's help reaches around 700 of the women, those who stay at the five government-run ashrams in the Vrindavan. There is no clear estimate of the total number of widows in the town, but it is believed that a majority live in rented accommodation, sharing a single room with many others. An NCW sample survey in 2009 found that $89 \%$ of Vrindavan widows were illiterate. Most had children or relatives, who refused to take care of them. Around $70 \%$ received no pension and almost $60 \%$ had no ration cards, forcing them to depend on alms and singing bhajan to survive.( Report, 2009, NCW).

Very often every year these women would watch men and women play Holi from the windows of their ashram. The celebrations of the town are legendary," said PushpaAdhikari, a widow from Bengal, who came to Vrindavan 17 years ago.( Times of India, March, 25 $\left.{ }^{\text {th }}, 2013\right)$. This year Bindeshwar Pathak, head of Sulabh International, which organized the event involved a large number of women in this festival of colour. They sang and danced, laughed and shed tears. They threw flowers at each other and played with gulal. The widows of Vrindavan celebrated Holi with a riot of colours on Sunday, defying tradition that bids them to stay away from festivities of all kind. It's a Holi of hope. The message that goes out from the celebration is that widows want to be part of the mainstream. They too have aspirations that should be fulfilled. That change would come slowly was evident at Sunday's Holi celebrations held at the MeeraSehbhaginiMahila Ashram. Most other widows, who live in government ashrams and have started receiving the Rs 2,000 stipend, sat quietly through the festivities. But they were out in the open proclaiming in their silence thither too have a right to be part of the living world.

Many of the widows of Vrindavan suffer from health issues. They have ailments that aren't getting proper treatment or attention. Javitri Tomar, a former resident of Kolkata who has a damaged leg, said the ashram officials wanted money to provide her with a wheelchair. LakkhiPatra, another ashram inmate from Bengal, said the diabetes medicine given to her by a doctor did not have any effect. She had to bring her stock of medicines from Bengal. But even the women who sat through the Holi function admitted that the day was special. "When LalBabhdurShastri, the then Prime Minister of India came to Calcutta, the streets were full of flowers. After that day, I'm seeing so many flowers for the first time," said a woman sitting in a chair away from the action.

Hence it is important to see the issues of Old age and give it a top priority in policy making. There is a need to sensitizing governments, NGOs, UN agencies and Donors to widows' issues and provide support widows organising themselves for collective work. There is very little information available on these widows. There is a need for better data collection and research on the social and economic status of widows, and on inheritance practices. There should be information on cruel mourning rites and reforming social customs that marginalise and torture widows. There is also a need to collect information 
on violence to widows, and sexual abuse in context of AIDS. We need to bring these widows into main stream and direct policies for a change in their status rather than just leaving them to their fate and at the mercy of religious institutions.. There is a need to provide them with training in income-generating activities. Last but not least let us treat the widows as human beings and bring them into the main stream of the Women's Movement.

\section{References}

Ageing Social Policy and Development Division, http://undesadspd.org/Ageing.aspx accessed on $24^{\text {th }}$ August, 2013.

Bevinamar, Kavita S, (2012). Problems of Elderly Women: Need for Intervention, Indian Streams Research Journal, vol. 1, issue, V.

Chant, Sylvia, (2006). "Re-thinking the "Feminization of Poverty" in Relation to Aggregate Gender Indices", Journal of Human Development 7 (2): pp. 201-220.

Chen, Mary and JeanDreze, (1993). Widows in Rural North India and Widows and WellBeing in Rural North India, Development Economics Programme, LSE London.

Chen, Alter Martha, (1998). Widows in India: Social Neglect and Public Action. New Delhi: Sage Publications,

Dalal, Sucheta, (2006). 'Desperately Needed: Senior Citizen's Alert', Indian Express, Mumbai, August 21, p 8.

Dreze, Jean and Marty Chen, (1995). Recent Research on Widows in India-Workshop and Conference Report, Economic and Political Weekly vol. - XXX, no. 39, September 30 .

Gopal, Meena, (2006). "Gender, Ageing and Social Security", Economic and Political Weekly, October 21, pp. 4477-4486.

Krishnaraj, Maithreyi, (1999). "Ageing Women in a Welfare State Cracks in the Utopia?", Economic and Political Weekly, October 30, pp. WS 75-88.

Madrid International Plan for action on age, http://www.helpageindiaprogramme.org/ other/Publications/Mippa\%20folder.pdf, accessed on 22 ${ }^{\text {nd }}$ August, 2013. 
Report, NCI, National Commission for Women, (2009-10). Study on widows at Vrindavan.

Report, 2011, Situation Analysis Of The elderly in India ,Central Statistics Office Ministry of Statistics \& Programme Implementation ,Government of India. http://mospi.nic.in/mospi_new/upload/elderly_in_india.pdf $\quad, \quad$ accessed $24^{\text {th }}$ August, 2013.

Report, National Policy on Older persons, Ministry of Social Justice and Empowerment, New Delhi. http://www.tiss.edu/tiss-attachements/downloads/national-policy-forolder-person-npop, accessed on $25^{\text {th }}$ August, 2013.

Soodan, Kirpal Singh, (1995). Aging in India, Calcutta: Minerva Associates Publications.

Times of India, (2013). Holi of hope for Vrindavan widows, by Amit Bhattacharya,25 March.

United Nations. (1987). Population Ageing: Review of Emerging Issues, Asian Population Studies, Series No.80, Economic and Social Commission for Asia and the Pacific, Bangkok, Thailand.

Vienna International plan of action on aging, 1983, United Nations, New York. http://www.un.org/es/globalissues/ageing/docs/vipaa.pdf, accessed on $24^{\text {th }}$ August, 2013.

Wennerholm, Carolina Johansson, (2002). The 'Feminisation of Poverty' Swedish, International Development Cooperation Agency, SIDA, Stockholm, Sweden, http://www.sida.se/Publications/Import/pdf/sv/The-quotFeminisation-ofPovertyquot-The-use-of-a-concept_2621.pdf, accessed 24 ${ }^{\text {th }}$ August, 2013.

Rekha Pande is Professor and Head of the Department of History, Joint Faculty, Centre for Women's Studies, School of Social Sciences, University of Hyderabad, Telangana, India. 